\begin{abstract}
Iranica
Abstracta Iranica Revue bibliographique pour le domaine irano-aryen

Volume 42-43 | 2021

Comptes rendus des publications de 2019-2020

\section{Josef Wiesehöfer. "Women of the Sassanid Dynasty (224-651 CE)"}

\title{
Domiziana Rossi
}

\section{(2) OpenEdition \\ 1 Journals}

\section{Electronic version}

URL: https://journals.openedition.org/abstractairanica/52613

DOI: 10.4000/abstractairanica.52613

ISSN: 1961-960X

Publisher:

CNRS (UMR 7528 Mondes iraniens et indiens), Éditions de l'IFRI

\section{Electronic reference}

Domiziana Rossi, "Josef Wiesehöfer. "Women of the Sassanid Dynasty (224-651 CE)"', Abstracta Iranica [Online], Volume 42-43 | 2021, document 20, Online since 15 April 2021, connection on 13 December 2022. URL: http://journals.openedition.org/abstractairanica/52613 ; DOI: https://doi.org/ 10.4000/abstractairanica.52613

This text was automatically generated on 13 December 2022.

All rights reserved 


\title{
Josef Wiesehöfer. "Women of the Sassanid Dynasty (224-651 CE)"
}

\author{
Domiziana Rossi
}




\section{REFERENCES}

Josef Wiesehöfer. "Women of the Sassanid Dynasty (224-651 CE)" in Elizabeth D. Carney, Sabine Müller (eds.). The Routledge Companion to women and monarchy in the Ancient Mediterranean World. London/New York: Routledge, Taylor \& Francis Group, 2020, p. 246-255.

1 Although there is much evidence on Sasanian kings, we know little about their wives not even the two attested ruling queens of the dynasty. Foreign and non-contemporary narratives often help to reconstruct this female world, with all the related problematics.

2 Wiesehöfer divides royal women into three 'chronological' paragraphs, based on primary (i.e., rock reliefs, seals, inscriptions, coins, silver vessels), foreign (including internal sources but from a different ecumene than the royal one, i.e., Greek, Latin, Jewish, Manichean), and non-contemporary (e.g., Khusraw and a page and al-Ṭabarī's Ta'rik al-rosul wa'l-moluk) sources.

3 After this very necessary compendium covering most of the attested women of the Sasanian dynasty, a conclusive note follows, which concludes that their titles were linked to social rank rather than family status. Also noteworthy is also the underlining of how Sasanian women seems to be more meaningfully powerful than the Arsacid ones. This is seen in several scenarios, including Sasanian queens having an audience together with the king, being regents, and last but not least, being crowned queens. Another interesting aspect raised is the question on the 'itinerant court', confirmed by the fate of the family of Narseh and Peroz. The fact that the court, including Sasanian royal women, sometimes followed the king while away on war is confirmed by their families being captured by the enemies.

\section{AUTHORS}

DOMIZIANA ROSSI

Cardiff University 